\title{
Reasons for Implementing Public-Private Partnership in Road Construction: Perspective from State-Owned Agencies and Private Sector in Ghana
}

\author{
Simon O fori Ametepey ${ }^{1}$, William Gyadu-A siedu ${ }^{1}$ and Clinton Aigbavboa ${ }^{2}$ \\ 1Faalty of Built andNatural Enuronment, Kforidua Tehnical University, Koforidua- Ghama \\ ${ }^{2}$ Departmet of ConstructionManagement \& Quantity Survejing Univesity ofJdhannesarg Doomfontein Campus, Jdannesarg Sath \\ Africa
}

\begin{abstract}
Presently, there is a request by various stakeholders in the road construction sector to embrace public-private partnership (PPP) as an alternative means of solving the road infrastructure deficit in Ghana. To this end, the study sought to identify the underlying reasons for implementing public-private partnership in road construction in $\mathrm{G}$ hana. It also intends to examine the differences in the perception of these reasons by the State-owned Road Agencies (SRA) (who represent the government) and the Private Sector (PS). A questionnaire survey was used to elicit the perceptions of the SRA and PS on the underlying reasons for implementing PPP in road construction in G hana. An in-depth interview was also conducted among four PPP "experts" in Ghana. Seventy-six functional responses were analysed using Statistical Package for the Social Science (SPSS) to rank the importance of the reasons based on the overall responses, as well as the responses from both the SRA and the PS and to examine the differences in the perceptions between the two groups. "Shortage of government funding", "Political pressure", "Economic development pressure of demanding more facilities", "accelerate project development", "Allowance for shared risk", "Ability to raise funds for project by private sector", and "Facilitate creative and innovative approaches" were found to be the seven most important reasons for adopting PPP in road construction in Ghana. In terms of the differences in perception between the SRA and PS groups, the hypothesis test results indicated that significant differences exist for only a few of the reasons.
\end{abstract}

Keywords:Reasons; G hana; Public-private partnerships; Infrastructure, Road Construction

Citation: Ametepey S. O, Gyadu-Asiedu W, Aigbavboa C. Reason for implementing public-private partnership in road construction: perspective from state-owned agencies and private sector in G hana, 2018; 3(1): 23-34.

Reciveed: 22 Nowerber 2017

Accepted: 21Deeenber 2017

\subsection{Introduction}

Governments are aware that an underdeveloped road network is likely to be associated with sub- optimal economic performance and quality of life. It is no surprise, therefore, that governments are constantly looking for ways to develop their road networks and other transport links to meet their economic, political and social needs. In some jurisdictions this will mean building brand new roads, in others it will mean focusing on refurbishing, widening and extending existing roads. The nature of road projects varies considerably from project to project and is driven by the local, national or even international factors that make the project a necessity in the first place. New roads are expensive and governments are often unable or unwilling to commit fiscal spending to roads. This is an area where Public-private 
partnership (PPP) is becoming more and more common. Presently, there is a request by various stakeholders in the road construction sector to embrace PPP as an alternative means of solving the road infrastructure deficit in G hana.

PPP is a globally accepted public sector procurement mechanism whereby the government engages commitment from the private sector and transfers a certain level of responsibilities to the private sector in providing public facilities or services. PPP in the broadest form refers to any relationship between the public and private sectors in delivering goods, services, and infrastructure (Friend, 2006). However, different countries may have different definitions of PPP. In many countries, PPP is defined as a long-term business relationship between the government and private sectors to provide public services whereby the risks and returns are shared (Reijniers, 1994; Grimsey and Lewis, 2002; Klijin and Teisman, 2003; Startin et al., 2009). More specifically, PPP in the Ghanaian context is defined by the Ministry of Finance and Economic Planning (2011) as a contractual arrangement between a public entity and a private sector party with clear agreement on shared objectives for the provision of public infrastructure and services traditionally provided by the public sector.

The variances in the features of PPP between countries reflect the unique motivations for implementing PPP in each country (Ismail, 2014). In Ghana PPP is fairly new. It gained some attention in early 2000 when the government was faced with the huge infrastructure deficit in the midst of limited budget resources. In 2004, G hana developed its first PPP policy guidelines but was not operationalized. This was enhanced and adopted in 2011 to guide the PPP development process and to provide a clear and consistent process for all aspects of PPP project development and implementation from projectidentification, appraisal, selection, to procurement, operation and maintenance and performance monitoring and evaluation (MOFEP, 2011).

In the context of developing countries, there are differences in terms of what actually drives governments to adopt PPP. While some PPP experts are of the opinion that most developing countries accept the PPP policy as a condition on loans from International Organizations (Jamali, 2004; Thomas et al., 2006; Appuhami et al., 2011), others raise the argument that some engage in PPP to alleviate poverty in their countries (Bhatia \& Gupta, 2006). In spite of the controversy about PPP policy in developing countries, most developing economies actually have huge infrastructure deficit and excessive government debts which in a way has led to the poor economic development and lower standards of living. This makes it more important for PPP to be explored in these developing countries to boost infrastructure development and improve the living standard of the people.

Realizing the various factors attracting PPP implementation in different countries, this present study aims to assess the reasons for implementing PPP in road construction in G hana. Though a study (O sei-Kyei, D ansoh\&Ofori-Kuragu, 2014) has been conducted on the reasons for adopting PPP for construction projects in Ghana, this present study focuses on the road construction sector which is a significant part of infrastructure projects. In ensuning that the government's agenda for greater private sector participation via the PPP program in road construction is achieved, it is crucial to identify the factors that attract the private and public sectors to participate in PPP. Hence, this study aims to offer some evidence on this issue. Specifically, there are two objectives of the present study. First, it assesses the reasons for adopting PPP for road 
construction in Ghana as perceived by the SRA and PS groups. Second, the study intends to assess the differences between the SRA and PS in terms of their perception of the importance of the underlying reasons.

This article is exceptional in the sense that it highlights not only the important underlying reasons for adopting PPP in road construction Ghana but also offers evidence on the differences in the perceptions of the two key parties involved in PPP (i.e., the SRA and the PS) in relation to the reaons. It is vital to put forward the differences of opinion of the two parties because each party plays a different role in a PPP contract.

The remainder of this paper is structured as follows. The next section reviews relevant literature concerning the reasons in adopting PPP. This is followed by a methodology section, which describes the instrument used, sample and data collection and analysis procedures. The results are discussed in the subsequent section, followed by suggestions for future research and the conclusion in the final section.

\subsection{Reasons for ImplenentingPPP}

Most governments over the world attempt to adopt PPP in procuring infrastructure projects but each has a reason for adopting the policy.Li (2003) and Li et al. (2005) conducted a survey to examine the factors attracting PPP implementation in the UK. The authors identified 15 attractive factors upon extensive literature search: "solves the problem of public sector budget restraint", "enhances government integrated solution capacity", "reduces public money tied up in capital investment", "caps the final service costs", "reduces the total project cost", "saves time in delivering the project", "reduces public sector administration costs", "benefit to local economic development", "non-recourse or limited recourse public funding", "transfer of risk to the private partner", "improves maintainability", "facilitates creative and innovative approaches", "improves buildability", "accelerates project development" and "technology transfer to local enterprise". Li (2003) stated that "transfer of risk to the private partners" is perceived as the top attracting factor for PPP implementation in the UK. Other important attractive factors include "solves the problem of budget restraint" and "non-recourse or limited recourse public funding". Additionally, Li et al. (2005) examined the differences between the perception of the public sector and private sector respondents concerning the importance of the 15 attractive factors. The authors established that there were only significant differences for three factors between the two key PPP players.

Also, a study was carried out in 2005 to examine the factors motivating various stakeholders (i.e. government, nongovernmental organizations (NGOs), international organizations (IOs) and private company) to implement a community development programme in Myanmar using the PPP approach (LaFrance \& Lehmann, 2005). The study revealed that various stakeholders have different key incentives for adopting PPP. For example, the motivations of the government for having PPP are to support the country's development and to benefit the citizens with improved services. For the NGOs, PPP is seen as a mechanism for them to share expertise and to improve transparency in the public management. In the same way, private sector companies are motivated to become involved in PPP in order to provide technical knowledge, skill, andexperience in delivering public services, and, at the same time, to gain a reasonable return on financial and technical investment. 
A questionnaire survey was carried out by Cheung et al. (2009) to investigate the reasons for implementing PPP in Hong Kong, Australia, and the UK. The study revealed similarities and variances in the reasons for PPP implementation between the countries. The top three motivations for implementing PPP in Australia, are "high quality of services required", "economic development pressure demanding more facilities" and "inefficiency because of public monopoly and lack of competition". In Hong Kong, the three key reasons are "private initiative", "economic development pressure demanding more facilities" and "high quality of services required". The main reasons for implementing PPP in the UK are "shortage of government funding", "economic development pressure demanding more facilities" and "avoid public investment restriction".

Prior studies have highlighted various factors that have attracted various parties to engage in PPP projects. According to Hall (1998), the rationales for a country to prefer the use PPP to execute public projects are that the private sector is inherently more efficient and more innovative than the public sector, the private sector has the advantage of competitive pressures in the delivery of public services and the private sector might be able to manage some types of risk more effectively than the public sector, which ultimately lead to a better quality of services provided, cost savings and the reduction of risks taken on by the government.

Hodges and Mellett (2004) also underscored the advantages of PPP, which were comparable to those mentioned by Hall (1998) and in addition, they indicated that PPP can reinforce project monitoring and ensure greater accountability. Also, Leiringer (2006) claimed that governments across the world are favouring PPP because of reasons such as lower project costs, shorter construction times, competitive advantages, higher overall qualities in the end product and the benefits accrued from letting the private sector be innovative in its solutions. Mumford (1998) identified the following six sources of savings of PPP over conventional procurement options: clearer definition and specification of user needs, more careful lifetime design and costing by the private constructor, speedier construction, and commissioning, more effective monitoring of contracts, incentives that better align effort with risk and rewards, and decision-making that better exploits asset compatibility.

Hurst and Reeves (2004) stated that the major attractions of PPP for the government are the potential of accruing efficiency and value for monetary gains from the projects. Because PPP promotes private sector innovation, an improvement of the dynamic efficiency as well as of the quality of services can be achieved. Jamali (2004) viewed PPP as an innovative policy tool to lessen the lack of dynamism in traditional public services.

Vining and Boardman (2008) stated three major rationales about why governments engage in PPP. First, PPP seems to minimise the government's budget on expenditures. Second, both the provision of the infrastructure and the services by the private sector are at a lower cost because of the economies of scale, more experience, better incentives and a greater ability to innovate. The third rationale is it reduces the government's risk, particularly during the design and construction phase as well as the operating phase. Reeves and Ryan (2007) recommended a number of benefits from PPP implementation, including faster delivery of public infrastructure, a drop in public spending and a better value for money compared to traditional methods of procurement. 
In light of the above literature, the factors attracting both parties' (i.e., the government and private sectors) involvement in PPP can be summarised as follows: solve the problem of public sector restraint, provide integrated solutions, reduce public money tied up in capital investment, facilitate creative and innovative approaches, reduce the total project cost, save time in delivering the project, transfer risks to the private sector, reduce public sector administrative costs, benefit local economic development, improve buildability, improve maintainability, non-recourse or limited recourse to public funding and accelerate project development. More importantly, based on earlier studies, particularly by Li et al. (2005) and Cheung (2009), the results show that the attractive factors perceived by the respondents in the UK are different from the factors perceived by the respondents in Hong Kong and Australia. This finding implies that the unique characteristics of PPP in each country influence the PPP attractiveness in the country. Consequently and because there is no similar evidence in the Ghanaian context especially in the road construction sector, this study investigates the attractive factors for PPP implementation in road construction in Ghana.

\subsection{Methodology}

To identify and prioritise reasons for implementing PPP in road construction in G hana, a thorough review of literature was conducted. Twenty-Eight reasons were identified (Chan et al., 2006; A kintoye et al., 2003; Cheung et al., 2010; Li et al., 2005; Ismail, 2013; O sei-Kyei et al., 2014 etc.). Since the reasons gathered from the literature had been sufficiently tested and used in similar studies in other countries, they were used as the basis for the present study. A multiple research approach involving in-depth interviews and questionnaire survey was adopted for the study. In-depth interviews were carried out prior to the questionnaire survey to examine the relevance of the identified reasons in the $G$ hanaian context. The reasons were reduced to twenty-two after the interview.

Senior Engineers, Quantity Surveyors and Directors with the state-owned road agencies who have some training in PPP i.e. Ghana Highway Authority (GHA), D epartment of Urban Roads (DUR), Department of Feeder Roads (DFR), and Ministry of Roads and Highways (MRH) and also potential private sector organisations interested in investing in the road sector were involved in the study. Four PPP "experts" were involved in the in-depth interview prior to the questionnaire survey. The entire respondents were purposively selected to ensure organisations and individuals that were best placed, could be accessed and were willing to provide the needed information were consulted for the required information. O ne hundred and twentyeight (128) respondents participated in the questionnaire survey. The questionnaire used consists of 22 reasons for implementing PPP as an alternative to the traditional procurement, as shown in Table 1. The questionnaire prepared adopted closed-ended questions but options were given for respondents to add to the list of possible answers. The respondents were asked to rate the importance of each reason based on a five-point Likert scale from (1) most important to (5) not important.

Table 1

Reasons for implementing PPP

\begin{tabular}{ll}
\hline No. & Reasons \\
\hline & Economic development pressure of demanding more \\
2 & facilities \\
3 & Political pressure \\
4 & Social pressure of poor public facilities \\
& Shortage of government funding
\end{tabular}


5 Public monopoly and lack of competition

$6 \quad$ High-quality services required

Lack of business and profit generating skill in the public

7 sector

8 Better resource mobility by private sector

$9 \quad$ Ability to raise funds for project by private sector

10 Enhances technology transfer to the local enterprise

11 Allows for shared risk

12 Reduces public sector administration cost

13 Facilitate creative and innovative approaches

14 Reduces the total project cost

15 Accelerate project development

16 Benefit local economic development

17 maintenance

Provide an integrated solution (for public

18 infrastructure/ service)

19 Increases access to the public sector market

20 Reduces the problem of public sector budget restraint

21 Provides incentives to new market penetration

22 Provides government assistance in financing

Each questionnaire was administered through a face-to-face session which ensured that 76 questionnaires out of the 128 were returned complete and used in the analysis, representing a response rate of 59\%. The data were analysed using the Statistical Package for the Social Sciences (SPSS) software. The descriptive statistic of the mean score was computed for the five-point Likert scale based on the importance of each of the 22reasons. Then, based on the mean scores, the reasons were

ranked according to the importance as perceived by the overall respondents as well as by the SRA and PS independently. An independent sample t-test was carried out to statistically examine the differences in the perceptions of the two groups of respondents.

\subsection{Hypothesis testing}

From literature it is predictable that the SRA and PS might have diverse views as to a particular reason for implementing PPP in road construction in Ghana. Based on this, a hypothesis testing using independent sample ttestwas carried out to determine the differences in views for using PPP in road construction. If the Significant value calculated is less than the significant value set (0.05) then the Null Hypothesis (Ho) is rejected.

Null Hypothesis (Ho) - There is no difference in the views of SRA and PS on reasons for implementing PPP in road construction in Ghana.

\subsection{BakgraundInfomation of Respondents}


O ut of 76 respondents, 40.8 percent of the respondents are employed with private sector companies while the remaining 59.2 per cent are engaged in public sector, as represented in Table 2. From Table 2, majority of the respondents are managers, directors and heads of departments in their organizations respectively. This makes them the main decision makers thus information from them is extremely dependable. Besides, $38.2 \%$ of the total respondents are operational staff who are mostly exposed to the partnership complexity and are also responsible for handling the technicalities of the partnership deals. More than half of the respondents have PPP experience less than 5 years and between 6 to 10 years. It is not surprising that most respondents experience in PPP project are between 1 to 10 years as PPP policy was introduced in Ghana in 2004 (MO FEP, 2011) and since then some projects have been embarked on at the various central and local levels. On the other hand, 15.8\% of the total respondents have PPP experience between 11 and 20 years. However, given that this policy was introduced in Ghana in 2004, it is projected that these respondents had engaged in PPP projects outside Ghana. Largely, the background of the respondents reveals their credibility in providing reliable information for the purpose of the present study.

Table 2

Background Information of Respondents

\begin{tabular}{|c|c|c|c|}
\hline & & Frequency & $\begin{array}{c}\text { Percentage } \\
\%\end{array}$ \\
\hline \multirow{3}{*}{$\begin{array}{l}\text { Category of } \\
\text { Respondents }\end{array}$} & \multirow{2}{*}{$\begin{array}{l}\text { Public } \\
\text { Private }\end{array}$} & 45 & 59.2 \\
\hline & & 31 & 40.8 \\
\hline & Total & 76 & 100 \\
\hline \multirow[t]{5}{*}{ D esignation } & $\begin{array}{l}\text { Head of } \\
\text { D ept }\end{array}$ & 14 & 18.4 \\
\hline & Director & 18 & 23.7 \\
\hline & $\begin{array}{l}\text { Operational } \\
\text { Staff }\end{array}$ & 29 & 38.2 \\
\hline & Manager & 15 & 19.7 \\
\hline & Total & 76 & 100 \\
\hline \multirow[t]{5}{*}{$\begin{array}{l}\text { Experience in } \\
\text { PPP }\end{array}$} & \multirow{5}{*}{$\begin{array}{l}\text { below } 5 \text { yrs } \\
6-10 \text { yrs } \\
11-15 \text { yrs } \\
16-20 \text { yrs }\end{array}$} & 30 & 39.5 \\
\hline & & 34 & 44.7 \\
\hline & & 8 & 10.5 \\
\hline & & 4 & 5.3 \\
\hline & & 76 & 100 \\
\hline
\end{tabular}

\subsection{Results and Discussions}

In this section, findings on the overall results on the underlying reasons is presented, followed by findings on differences between the SRA and PS on the reasons.

\subsection{Reults of theReesons}

Table 3 illustrates the mean scores and the rank of the importance of each of the 22 reasons based on the overall respondents and the sector (i.e., public and private sectors). The respondents rated each reason based on a five-point Likertscale where 1 means not important and 5 means most important. The results in Table 3 show that all the 22 reasons were perceived by each group of respondents to be either "most important", "important" or "moderate" because the mean scores for the reasons range from 4.332 to 2.340 . 


\subsection{Overall respondats peceptions on theimpatance f thereasons}

Based on the mean score results of all respondents, seven reasons were perceived as "most important" and have mean scores above 4.021. The reasons, in descending order of importance, are: (1) Shortage of government funding, (2) Political pressure, (3) Economic development pressure of demanding more facilities, (4) accelerate project development, (5) Allows for shared risk, (6) Ability to raise funds for project by private sector, and (7) Facilitate creative and innovative approaches.

"Shortage of government funding" is the first most important reasons for adopting PPP in road construction in Ghana as perceived by the overall respondents. PPP is widely adopted by the government of many countries because it is claimed that having the private sector take on a significant responsibility to construct, finance, operate and maintain public infrastructure could reduce government allocation for development projects (Peat, 1995; Robinson, 2000). This is evident in studies by Li et al. (2005) and Cheung (2009), who discovered this factor as among the top factors attracting PPP adoption in the UK and Hong Kong, respectively. This finding is further explained by the main justification for the government to engage private sector companies in the development and economic activities of the country as a result of government budget restraints.

The second most important reason for adopting PPP in road construction in Ghana as perceived by the respondents is "political pressure". Road construction in G hana is solely the responsibility of Government. As a result, most political parties during elections promise to construct roads all over the country. Hence, when they win an election, they are faced with political pressure to deliver their promise of constructing the roads in the face of budgetary constraints. The respondents perceive this to be the reason for involving private sector companies via PPP in providing road infrastructure. This result sharply contradicts that of Ismail (2014) and Cheung et al. (2009) where in Malaysia, Australia, and Hong Kong, the "political pressure" factor was rated as low. Another most important reason for adopting PPP in road construction as rated by the respondents and in third place is "Economic development pressure of demanding more facilities".

In Ghana's quest to rapidly grow its economy, there is the need to have good roads to facilitate business as good road is linked with optimal economic performance. Thus, there is pressure on government to build some vital roads to facilitate its economic growth. The government seeks to achieve this through the involvement of the private sector via PPP. The finding is consistent with Ismail (2014), Cheung (2009) and Cheung et al. (2009) who also reported the factor as among the top motivations for implementing PPP in Hong Kong and Australia.

The reason ranked fourth by respondents is "accelerate project development". Road projects in G hana are characterized by time and cost overrun. In particular, the government was attracted to PPP because it has been proven from the experience of other countries that by using PPP, public projects were delivered on time, if not ahead of schedule and at a lower cost (Abdul Aziz, 2010; Abdul Aziz and Kassim, 2011). For example, it was reported that a number of PPP road projects in Malaysia were made available earlier than if the projects had been undertaken using the traditional government procurement method (Economic Planning Unit, 2001; 2006). Ismail (2013) finding was in line with this study. However, the finding contradicts that of Cheung, Chan, and Kajewski (2009) where respondents in the UK perceived the factor to be low.

Another most important reason ranked fifth by respondents is 'allows for shared nisk'. PPP as a partnership enables risk to be shared between parties. The private sector is well known for its ability to better manage risk through efficient asset 
procurement and service delivery. The Government of Ghana emphasizes that a partnership deal with the private sector cannot be considered as PPP unless there is considerable shared risk (MOFEP, 2011). It must be emphasized that risks must be identified and allocated to the party that can best manage it (Li et al., 2005).

The other most important reason is "private sectors ability to raise funds for projects". It is acknowledged all over the world that the private sector has the ability to mobilize resources well and is able to use limited resources efficiently and effectively (Skietrys et al., 2008). It is always the aim of every investor to minimize project cost and maximize revenue thereby managing available resources well and use them effectively to achieve its goal (Askar\& Gab-Allah, 2002), this is in no doubt why private investors possess such efficiency in project delivery. Moreover, road construction involves huge investment and many public agencies and departments lack the ability to raise funds for large-scale infrastructure projects (Walker et al., 1995). Therefore involving the private sector through PPP help lessen such shortfalls. This result is consistent with a study by O sei-Kyei, Dansoh, and O fori-Kuragu (2014).

Table 4

T-test results of the reasons for implementing PPP in road construction in Ghana

\begin{tabular}{|c|c|c|c|c|c|}
\hline No. & Attractive Factors & $\mathrm{F}$ & $\mathrm{T}$ & Sig & Decision \\
\hline 1 & Economic development pressure of demanding more facilities & 0.824 & -0.445 & 0.589 & Accept Ho \\
\hline 2 & Political pressure & 0.053 & -0.375 & 0.752 & Accept Ho \\
\hline 3 & Social pressure of poor public facilities & 1.953 & -0.353 & 0.685 & Accept Ho \\
\hline 4 & Shortage of government funding & 0.584 & -2.843 & $0.035^{*}$ & Reject Ho \\
\hline 5 & Public monopoly and lack of competition & 0.068 & -2.365 & $0.026^{*}$ & Reject Ho \\
\hline 6 & High quality services required & 4.521 & -1.824 & 0.065 & Accept Ho \\
\hline 7 & Lack of business and profit generating skill in the public sector & 1.648 & -1.526 & 0.152 & Accept Ho \\
\hline 8 & Better resource mobility by private sector & 0.0865 & -0.462 & 0.653 & Accept Ho \\
\hline 9 & Ability to raise funds for project by private sector & 1.328 & -0.734 & 0.214 & Accept Ho \\
\hline 10 & Enhances technology transfer to the local enterprise & 0.758 & -2.559 & $0.025^{*}$ & Reject Ho \\
\hline 11 & Allowance for shared risk & 0.085 & -0.865 & 0.237 & Accept Ho \\
\hline 12 & Reduces public sector administration cost & 8.356 & -2.365 & $0.018^{*}$ & Reject Ho \\
\hline 13 & Facilitate creative and innovative approaches & 5.265 & -0.576 & 0.365 & Accept Ho \\
\hline 14 & Reduces the total project cost & 0.063 & -0.325 & 0.284 & Accept Ho \\
\hline 15 & Accelerate project development & 1.536 & -1.605 & 0.094 & Accept Ho \\
\hline 16 & Benefit local economic development & 0.717 & -1.045 & 0.068 & Accept Ho \\
\hline 17 & Improves public infrastructure management and maintenance & 0.323 & -0.364 & 0.436 & Accept Ho \\
\hline 18 & $\begin{array}{l}\text { Provide an integrated solution (for public } \\
\text { infrastructure/ service) }\end{array}$ & 0.036 & -0.896 & 0.263 & Accept Ho \\
\hline 19 & Increases access to the public sector market & 0.564 & -2.447 & $0.037 *$ & Reject Ho \\
\hline 20 & Reduces the problem of public sector budget restraint & 0.044 & -2.654 & $0.021 *$ & Reject Ho \\
\hline 21 & Provides incentives to new market penetration & 7.385 & -1.036 & 0.125 & Accept Ho \\
\hline 22 & Provides government assistance in financing & 0.067 & -0.545 & 0.343 & Accept Ho \\
\hline
\end{tabular}

The final most important reason perceived by respondents for using PPP in road construction is "Facilitate creative and innovative approaches". There has been evidence that by using PPP, the public can enjoy better quality services because PPP encourages the private sectors to be innovative and creative in delivering the projects ( $\mathrm{G}$ rimsey and $\mathrm{Graham}$, 1997; Treasury 
Taskforce, 1997). According to Kaliannan, Awang and Raman (2010), the private sector is perceived as being more innovative and efficient because it operates in a competitive commercial environment where there are incentives and rewards for meeting the needs of the customers (Kaliannan, Awang, and Raman, 2010). This result is similar to that of Ismail (2013).

\subsection{Differenesin thepereptions of thestateonnedrcad agenies and privatesetors respondants on theimpotance of thereasons}

In terms of the differences on the perceived importance of each reason by the SRA and PS, based on the mean score rankings, the results of the two parties are almost similar except for differences in the ranking for several reasons. Table 3 shows that some reasons were perceived to be more important by the SRA respondents than by the PS respondents, whereas some were perceived to be more important by the PS than by the SRA. In further examining the differences in the perceptions of the public and private sectors concerning the importance of each of the twenty-two reasons, an independent $t$ test was conducted. Table 4 reveals the independent sample t-test of responses with respect to hypothesis testing.

Based on the results shown in Table 4, the findings show that out of the twenty-two reasons there is no significant difference in the perceptions of the SRA and PS except in the cases of six reasons: "Shortage of government funding", "Public monopoly and lack of competition", "Enhances technology transfer to the local enterprise", "Reduces public sector administration cost", "Increases access to the public sector market" and "Reduces the problem of public sector budget restraint" which show a statistically significant difference at the $5 \%$ significance level. The result is in line with O sei-Kyei, Dansoh and O fori-Kuragu (2014), Ismail (2013) and Li et al. (2005). O sei-Kyei, Dansoh, and O fori-Kuragu (2014) revealed that public and private sector respondents in Ghana have different perception in terms of the reasons for implementation. Ismail (2013) reported that the public sector respondents in Malaysia perceived the reasons as more important than the public sector while Li et al. (2005) reported that the private sector respondents in the UK perceived the reasons as being more important than the public sector respondents.

The public sector respondents perceived three reasons "Enhances technology transfer to the local enterprise", "Reduces public sector administration cost", and "Reduces the problem of public sector budget restraint" as significantly more important than the private sector respondents. Similarly, the private sector respondents also perceived three reasons "Shortage of government funding", "public monopoly and lack of competition", and "Increases access to the public sector market" as significantly more important than the public sector respondents.

\subsection{Conclusion}

The study adopted in-depth interview to examine the relevance of the identified reasons in the Ghanaian context. A questionnaire survey was subsequently used to examine the reasons for implementing PPP in road construction in Ghana. Besides, this paper assessed the differences in the perception of the SRA and the PS, in terms of each attractive factor. The general results show that "Shortage of government funding", "Political pressure", "Economic development pressure of demanding more facilities", "accelerate project development", "Allows for shared risk", "Ability to raise funds for project by private sector", and "Facilitate creative and innovative approaches" are the seven most important reasons for implementing 
PPP in road construction in Ghana. In terms of the differences in perception between the SRA and PS groups, the hypothesis test results indicated that there are significant differences for only a few reasons for implementing PPP.

The results of the top reasons for PPP adoption in road construction in Ghana are significant to the various PPP stakeholders, particularly the government, who introduce the policy and the private sector companies, who take significant responsibilities in carrying out projects via PPP. PPP is perceived as an attractive initiative because it requires private sector companies to form a special purpose vehicle (SPV) that comprises few companies with different expertise to jointly undertake a long term government project. To emphasise the need to form an SPV that comprises various private companies, in evaluating the tender for PPP, the government may consider assessing the credibility of each company that forms the SPV rather than only assess the construction company that will lead the PPP project. This leads to a greater possibility of a PPP project to succeed because all of the private companies that form the SPV are in a position to play appropriate roles throughout the PPP contract.

The differences in perception between the private and public sector respondents for several reasons for implementing PPP, which the public sector respondents perceived as being more important than the private sector respondents and vice versa, imply that the SRA and PS companies in G hana have divergent views about the desirability of PPP procurement, which may ultimately lead to some challenges in implementing PPP in road construction. In ensuring that the objectives of adopting PPP in road construction are achieved, it is vital that both parties have an equal priority towards PPP implementation.

There are some limitations to this study. First, the use of a case study approach may enrich the findings and lead to the triangulation of evidence on the reasons for PPP implementation in road construction in Ghana. Second, this study only evaluated the reasons for adopting PPP in road construction in G hana. Although this is important, it is also crucial to both the government and private sectors to have information on the factors that hinder the adoption of PPP in road construction. Hence, future studies may want to extend this study by also looking at this neglected issue. Despite its limitations, this study offers some insights and useful information for the SRA and private sector providers concerning the important reasons for implementing PPP in road construction in G hana.

\section{References}

1. Abdul Aziz, A.R. (2010). Housing private-public partnership: Perspective from the government agencies.Proceedngs 4thNAPREC Conference

2. Abdul Aziz, A.R. and Kassim, P.S.J. (2011). O bjectives, success and failure factors of housing public-private partnerships in Malaysia. Habitat Intemational, 35(1): 150-157.

3. Akintoye A, Beck M, Hardcastle C. (2003). Public-private partnerships: managing Beijing Municipal Commission of D evelopment and Reform. Proceedings of Intemational Fonumon InfrasturtureMarketization; Heict-Watt Univesity.

4. Appuhami R, Perera S, Perera H. (2011). Coercive policy diffusion in a developing country: the case of PublicPrivate Partnerships in SriLanka.J ContempAsia 41:431-451.

5. Askar M, G ab-Allah A. (2002). Problems facing partiesinvolved in build operate, and transport projects in Egypt. J ManageEng 18:173-178.

6. Bhatia B, Gupta, N. (2006). Lifting constraints to Public-Private Partnerships in South Asia. Washington, DC: World Bank. 
7. Cheung E, Chan APC, Kajewski S. (2010). Suitability of procuring large public works by PPP in Hong Kong. EngConstrArchiteeManage 17:292-308.

8. Cheung, E. (2009). Developing a best practiceframework for implementing public private partnerships (PPP) in Hong Kong. PhD diss. Queensland University of Technology.

9. Cheung, E., Chan, A.P.C. and Kajewski, S. (2009). Reasons for implementing public private partnership projects: Perspective from Hong Kong, Australian and British practitioners. Jaumal of PropetyInvestment andFinance, 27(1): 8195.

10. Economic Planning Unit. (2010) TenthMalaysia Plan(2011-2015)Available at dokumen attached/ speech/ files/ RMK10_Speech.pdf [Accessed on 22 May 2016].

11. Friend, J. (2006), "Partnership meets politics: managing within maze", International Journal of Public Sector Management, 19 (3): 261-277.

12. Grimsey, D . and Graham, R. (1997). PFI in the NHS.Engineeing ConstructionandArditetural Managenet, 4(3): 215231.

13. Grimsey D, Lewis MK. (2002). Evaluating the risks of public private partnerships for infrastructure projects. IntJ Prgiet Manage 20:107-118.

14. Hall, J. (1998). Private opportunity, public benefit. Fiscal Studies 19(2): 121-140.

15. Hodges, R. andMellett, H. (2004). Reporting PFI in annual accounts: A user's perspective. PublicMoneyand Management. 24(3): 153-158.

16. Hurst, C. and Reeves, E. (2004). An economic analysis of Ireland's first public private partnership. Intemational Jaumal of Public Setor Managmet, 17(5): 379-388.

17. Ismail, S. (2014),"D riving forces for implementation of public private partnerships (PPP) in Malaysia and a comparison with the United Kingdom", Jaumal of EconomicandAdministrativeSaienes 30 (2):82 - 95

18. Ismail, S. (2013)," Factors Attracting the Use of Public Private Partnership in Malaysia ", Jarmal of Constructionin DedqpingCantries, 18(1), 95-108, 2013

19. Jamali, D. (2004). Success and failures mechanisms of public private partnerships (PPPs) in developing countries. TheIntemational Jaumal of PublicSetor Management, 17(5): 414-430.

20. Kaliannan, M., Awang, H. and Raman, M. (2010). Public private partnerships for e-government services: Lessons from Malaysia. Intemational Jaumal of Institutions andEconomes, 2(2): 207-220.

21. Klijin, E.H. and Teisman, G.R. (2003), "Institutional and strategic barriers to public private partnership: an analysis of Dutch cases", PublicMoneyandManagemet, 23(3): 137-146.

22. LaFrance, J. and Lehmann, M. (2005), "Corporate awakening - why (some) corporations embrace public-private partnerships", Business StrategyandtheEnuronmet, 14(4): 216-229.

23. Leiringer, R. (2006). Technological innovation in PPPs: Incentives, opportunities and actions. Construction Managenent andEconomics 24(3): 301-308.

24. Li, B. (2003), "Risk management of construction public private partnership projects", $\mathrm{PhD}$ theis Glasgow Caledonian University, Glasgow

25. Li, B., Akintoye, A., Edwards, P.J. and Hardcastle, C. (2005). Perceptions of positive and negative factors influencing the attractiveness ofPPP/ PFI procurement for construction projects in the UK: Findings from a questionnaire survey. Enginering ConstructionandArhitectural Mamagmett, 12(2): 125-148.

26. Ministry of Finance and Economic Planning. (2011). National policy on Public _ Private Partnerships. Government of Ghana, Ghana.

27. Mumford, M. (1998). Extending the Private Finance Initiative. AcauntingandBusiness February, 32-33.

28. O sei - Kyei, R., D ansoh, A. \&Ofori - Kuragu, J. K. (2014) Reasons for adopting Public-Private

29. Partnership (PPP) for construction projects in G hana, Intemational Jaumal of ConstructionManagenent, 14:4, 227-238

30. Peat, J. (1995).Can the Private Finance Initiative be both expedited and cost-effective? TheTresure, September:4-6.

31. Reeves, E. and Ryan, J. (2007). Piloting public-private partnerships: Expensive lessons from Ireland's schools' sector. PublicMoneyandManagenet, 27(5): 331-338.

32. Robinson, P. (2000). The Private Finance Initiative: the real story. Custamer PdigyReiew10(3): 82-85.

33. Skietrys E, Raipa A, Bartkus EV. (2008). D imensions of the efficiency of public-private partnership. Engineering Economics. 3:45. 
34. Startin, J., Baxter, A and Harding, N. (2009), “Comparing public-private partnerships for highway projects in the USA and the UK/ EU: applying lessons learned”, Journal of Public Works \& Infrastructure, 1 (4):329-348.

35. Thomas AV, Kalidindi S, Ganesh L. S. (2006). Modelling and assessment of critical risks in BOT road projects. Constr Manage Econ. 24:407-424.

36. Treasury Taskforce. (1997). Partneshipfor Prospeity. London: Treasury Taskforce.

37. Vining, A. and Boardman, A. (2008). Public-private partnerships in Canada: Theory and evidence. Camadian Public Administration 51(1): 9-44.

38. Walker C, Mulcahy J, Smith A, Lam PTI, Cochrane R. (1995). Privatized infrastructure. London,UK: Thomas Telford. 